\title{
FY 2017 - Thermal Aging Effects on Advanced Structural Materials
}

Nuclear Engineering Division 


\title{
About Argonne National Laboratory
}

Argonne is a U.S. Department of Energy laboratory managed by UChicago

Argonne, LLC under contract DE-AC02-06CH11357. The Laboratory's main facility

is outside Chicago, at 9700 South Cass Avenue, Argonne, Illinois 60439. For

information about Argonne and its pioneering science and technology programs,

see www.anl.gov.

\section{DOCUMENT AVAILABILITY}

Online Access: U.S. Department of Energy (DOE) reports produced after 1991 and a growing number of pre-1991 documents are available free via DOE's

SciTech Connect (http://www.osti.gov/scitech/)

\author{
Reports not in digital format may be purchased by the public \\ from the National Technical Information Service (NTIS): \\ U.S. Department of Commerce \\ National Technical Information \\ Service 5301 Shawnee Rd \\ Alexandria, VA 22312 \\ www.ntis.gov \\ Phone: (800) 553-NTIS (6847) or (703) 605-6000 \\ Fax: (703) 605-6900 \\ Email: orders@ntis.gov \\ Reports not in digital format are available to DOE and DOE contractors \\ from the Office of Scientific and Technical Information (OSTI): \\ U.S. Department of Energy \\ Office of Scientific and Technical Information \\ P.O. Box 62 \\ Oak Ridge, TN 37831-0062 \\ www.osti.gov \\ Phone: (865) 576-8401 \\ Fax: (865) 576-5728 \\ Email: reports@osti.gov
}

Disclaimer

This report was prepared as an account of work sponsored by an agency of the United States Government. Neither the United States Government nor any agency thereof, nor UChicago Argonne, LLC, nor any of their employees or officers, makes any warranty, express or implied, or assumes any legal liability or responsibility for the accuracy, completeness, or usefulness of any information, apparatus, product, or process disclosed, or represents that its use would not infringe privately owned rights. Reference herein to any specific commercial product, process, or service by trade name, trademark, manufacturer, or otherwise, does not necessarily constitute or imply its endorsement, recommendation, or favoring by the United States Government or any agency thereof. The views and opinions of document authors expressed herein do not necessarily state or reflect those of the United States Government or any agency thereof, Argonne National Laboratory, or UChicago Argonne, LLC. 
ANL-ART-104

\section{FY 2017 - Thermal Aging Effects on Advanced Structural Materials}

Prepared by

Meimei Li, K. Natesan, and Wei-Ying Chen

Nuclear Engineering Division

Argonne National Laboratory

August 2017 




\section{ABSTRACT}

This report provides an update on the evaluation of the effect of thermal aging on tensile properties of existing laboratory-sized heats of Alloy 709 austenitic stainless steel and the completion of effort on the thermal aging effect on the tensile properties of optimized G92 ferritic-martensitic steel. The report is a Level 3 deliverable in FY17 (M3AT-17AN1602081), under the Work Package AT-17AN160208, "Advanced Alloy Testing - ANL" performed by the Argonne National Laboratory (ANL), as part of the Advanced Reactor Technologies Program.

Thermal aging experiments at 550,600 , and $650^{\circ} \mathrm{C}$ were carried out on three laboratorysized heats of Alloy 709 austenitic stainless steel, 709-01 (SAI Heat 12013806-709), 709-02 (CarTech Heat 11367), 709-05 (CarTech Heat 011502). Tensile tests were conducted at the aging temperature in air at a nominal strain rate of $0.001 \mathrm{~s}^{-1}$. It was found that thermal aging at $550^{\circ} \mathrm{C}$ had minimal effect on the tensile properties for times $<10,000 \mathrm{~h}$. Thermal aging at $600^{\circ} \mathrm{C}$ for $\sim 15,000 \mathrm{~h}$ slightly increased the yield stress and decreased the ultimate tensile strength (UTS). The effect of thermal aging at $650^{\circ} \mathrm{C}$ was more pronounced on the tensile properties of Alloy 709. An increase in the yield stress and a decrease in the UTS were accompanied by the reduction in the uniform and total elongations. The yield stress was increased by $\sim 34 \%$, the UTS was reduced by $\sim 9 \%$, and the uniform and total elongations were reduced by $\sim 50 \%$ and $\sim 36 \%$, respectively after aging for $\sim 20,000 \mathrm{~h}$ at $650^{\circ} \mathrm{C}$. The effect of thermal aging on tensile properties showed little variations among three heats of Alloy 709.

Four heats of optimized G92 ferritic-martensitic steel with or without thermo-mechanical treatment (TMT), including Opt. G92-3, Opt. G92-4, Opt. G92-4T, and Opt. G92-8T were investigated to evaluate the effect of thermal aging on the tensile properties of optimized G92. Conventional G92 (Heat G92-0) was included in the study to provide the baseline data. Thermal aging at $550-650^{\circ} \mathrm{C}$ caused a decrease in the yield stress and the ultimate tensile strength but had an insignificant effect on tensile ductility of optimized G92. The effect of thermal aging was stronger at higher temperatures and longer exposure times. The effect of thermal aging on tensile strength became evident after $\sim 10,000 \mathrm{~h}$ at $550^{\circ} \mathrm{C}, \sim 1,000 \mathrm{~h}$ at $600^{\circ} \mathrm{C}$, and $<1,000 \mathrm{~h}$ at $650^{\circ} \mathrm{C}$. The aging-induced reduction in tensile strength was much more pronounced at $650^{\circ} \mathrm{C}$ than at temperatures of $550-600^{\circ} \mathrm{C}$, and exhibited large variations among different heats of optimized G92. The heat with a higher initial tensile strength (e.g. Opt. G92-3 and Opt. G92-8T) showed a much greater reduction in strength than those with lower initial tensile strength (e.g. Opt. G92-4 and Opt. G92-4T). Microstructural characterization of optimized G92 showed subgrain coarsening, coarsening of $\mathrm{M}_{23} \mathrm{C}_{6}$ and $\mathrm{MX}$ particles, and precipitation of Laves phase after thermal aging at $650^{\circ} \mathrm{C}$. These microstructural changes can be correlated well with aginginduced tensile property degradation at $650^{\circ} \mathrm{C}$. 


\section{TABLE OF CONTENTS}

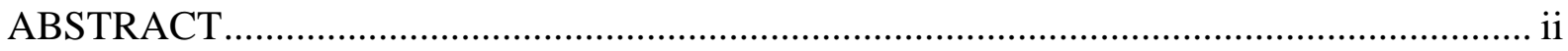

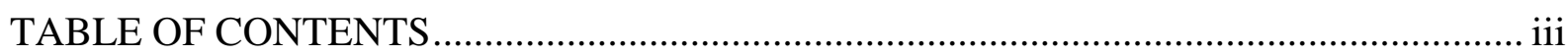

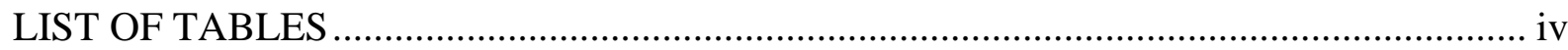

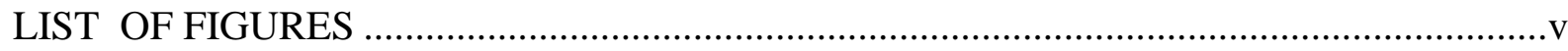

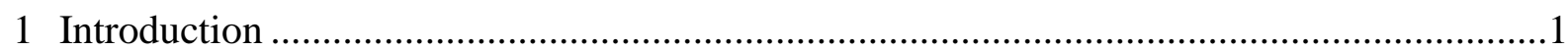

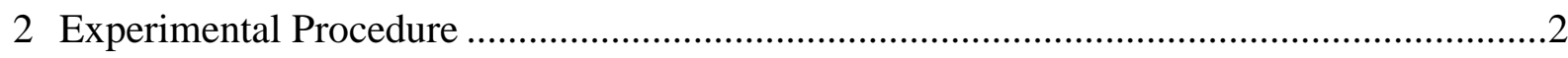

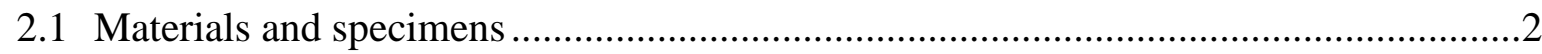

2.2 Thermal aging experiments.............................................................................

2.3 High temperature tensile tests ............................................................................6

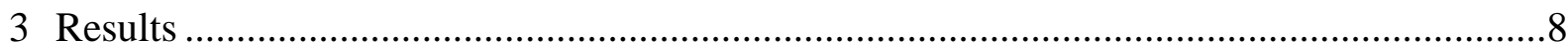

3.1 Effect of thermal aging on tensile properties of Alloy 709 .........................................

3.2 Effect of thermal aging on tensile properties of optimized G92 …..............................12

3.3 Effect of thermal aging on microstructure …………….............................................18

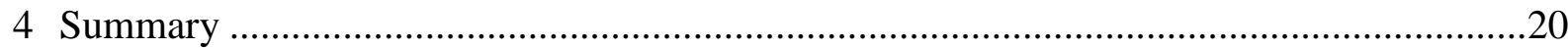

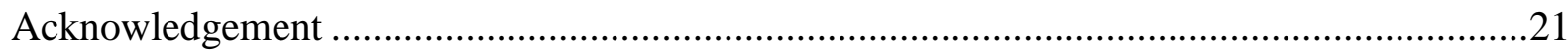

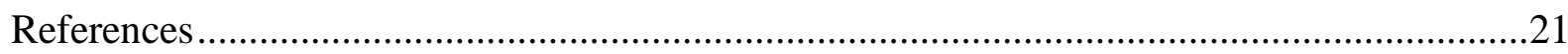




\section{LIST OF TABLES}

Table 1. Chemical composition of Alloy 709 (in wt $\%$ ) …….............................................

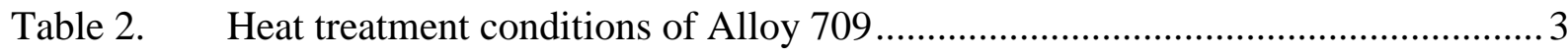

Table 3. Chemical composition of Opt. G92 and G92 (in wt\%) ........................................ 4

Table 4. Heat treatment conditions of Opt. G92 and G92. ............................................. 4

Table 5. Total thermal exposure times at 550, 600, and $650^{\circ} \mathrm{C}$ for Alloy 709, Opt. G92 and

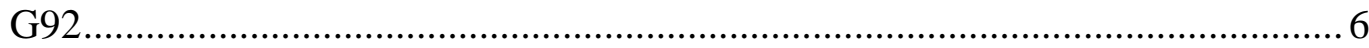

Table 6. Tensile properties of thermally-aged Alloy 709................................................ 11

Table 7. Tensile properties of thermally-aged Opt. G92 and G92 .................................... 16 


\section{LIST OF FIGURES}

Figure 1. Schematic drawing of subsize sheet-type tensile specimens used for thermal aging tests (a) the extended-grip tensile specimen used for microstructural characterization and tensile tests and (b) the specimen used for tensile tests........5

Figure 2. Thermal aging experiment (a) vacuum-encapsulated specimens and (b) hightemperature furnaces used for thermal aging tests........................................ 6

Figure 3. Experimental setup for high temperature tensile tests ................................ 7

Figure 4. The yield stress, ultimate tensile strength, uniform elongation and total elongation as a function of exposure time for Alloy 709 tensile tested at $550^{\circ} \mathrm{C}$ after thermal aging at $550^{\circ} \mathrm{C}$

Figure 5. The yield stress, ultimate tensile strength, uniform elongation and total elongation as a function of exposure time for Alloy 709 tensile tested at $600^{\circ} \mathrm{C}$ after thermal aging at $600^{\circ} \mathrm{C}$

Figure 6. The yield stress, ultimate tensile strength, uniform elongation and total elongation as a function of exposure time for Alloy 709 tensile tested at $650^{\circ} \mathrm{C}$ after thermal aging at $650^{\circ} \mathrm{C}$

Figure 7. The yield stress, ultimate tensile strength, uniform elongation and total elongation as a function of exposure time for Opt. G92 and G92 tensile tested at $550^{\circ} \mathrm{C}$ after thermal aging at $550^{\circ} \mathrm{C}$

Figure 8. The yield stress, ultimate tensile strength, uniform elongation and total elongation as a function of exposure time for Opt. G92 and G92 tensile tested at $600^{\circ} \mathrm{C}$ after thermal aging at $600^{\circ} \mathrm{C}$

Figure 9. The yield stress, ultimate tensile strength, uniform elongation and total elongation as a function of exposure time for Opt. G92 and G92 tensile tested at $650^{\circ} \mathrm{C}$ after thermal aging at $650^{\circ} \mathrm{C}$

Figure 10. Microstructure of Opt. G92-4 after thermal aging for 5,284 h at $650^{\circ} \mathrm{C}$ (a) TEM image of subgrains, (b) TEM image of dislocations, (c) TEM image of $\mathrm{M}_{23} \mathrm{C}_{6}$ (colored in blue) and MX (colored in green) precipitates, (d) SEM image of Laves phase, and (e) comparison of subgrain width, dislocation density, mean sizes of $\mathrm{M}_{23} \mathrm{C}_{6}$, MX and Laves phase particles in the as-received, thermally-aged $\left(650^{\circ} \mathrm{C} / 5,284 \mathrm{~h}\right)$, and sodium-exposed $\left(650^{\circ} \mathrm{C} / 4,370 \mathrm{~h}\right)$ conditions 



\section{Introduction}

The Advanced Reactor Technologies Campaign has focused on the sodium-cooled fast reactor concept because of its technical maturity. The current needs are for more reliable, more flexible, and more economical reactors suitable for commercial nuclear power generation. Research and development focuses on three areas including advanced materials, innovative components and systems, and computer modeling and simulation enabling predictions of longterm performance. Advanced materials are a key element in the development of advanced nuclear energy systems. High-performance structural materials allow for a compact and simple design of the reactor structure, and have the potential to reduce the construction and operational costs for next-generation nuclear reactors. Several advanced alloys were selected for further development in support of sodium-cooled fast reactors (Busby et al 2008). Advanced materials development efforts under the Advanced Reactor Concepts from FY2008 to FY2012 led to the down-selection of an advanced austenitic stainless steel, Alloy 709 and a ferritic-martensitic steel, optimized Grade 92 with thermo-mechanical treatment (TMT).

Alloy 709 (Fe-20Cr-25Ni-1.5Mo-Nb,B,N) has a significantly higher strength than conventional Type 304 and 316 austenitic stainless steels, and is considered as one of the best austenitic stainless steels for elevated temperature structural applications among commerciallyavailable austenitic alloy classes. The high strength of Alloy 709 is achieved by controlling the carbon content to $0.07-0.10 \%$ and precipitation strengthening by MX precipitates. Alloy 709 also shows good fabrication properties and weldability.

Optimized Grade 92 (Fe-9Cr-0.5Mo-2W-V,Nb) is a variant of commercially available Grade 92 ferritic-martensitic steels with tighter control of chemistry and thermo-mechanical treatment to achieve improved high temperature performance. Optimized G92 with and without thermomechanical treatment (TMT) has been developed in the United States for its potential applications for structural components in advanced sodium-cooled fast reactors. Though the alloy shows enhanced creep properties, good cross-weld creep performance, and comparable fatigue/creep-fatigue performance to commercial G92 steels [1], its sodium compatibility and the effect of sodium exposures on microstructure and mechanical properties have not been fully addressed.

While these advanced alloys have showed enhanced performance over current generation of high temperature structural materials, one of the major concerns in their structural applications in sodium-cooled fast reactors is their long-term microstructural stability and associated degradation of mechanical properties during service. Our previous work has showed that tensile properties of these advanced materials degrade with time, when exposed to high temperatures and liquid sodium. Significant microstructural changes during prolonged thermal and sodium exposures can lead to dramatically different responses to service environments. The objective of this project is to evaluate the effect of long-term thermal aging on the tensile properties of advanced alloys, Alloy 709 and optimized G92 (Opt. G92). This report presents continued effort on evaluating the effect of long-term thermal aging on tensile properties of Alloy 709 of laboratory-sized heats and the completion of effort on understanding the thermal aging effect on tensile properties of Opt. G92. 


\section{Experimental Procedure}

\subsection{Materials and specimens}

Three laboratory-sized heats of Alloy 709 were studied, i.e. 709-01, 709-02, and 709-05:

- Alloy 709-01 (SAI Heat 12013806-709) was made by Sophisticated Alloys Inc. It was hot rolled at $1150^{\circ} \mathrm{C}$ from $\sim 4$ " thickness to $\sim 1$ " with $10-15 \%$ reduction each pass, and stress relieved at $1150^{\circ} \mathrm{C}$ for $0.5 \mathrm{~h}$, followed by water quenching.

- Alloy 709-02 (CarTech Heat 11367) was made by Carpenter Technology. Two 1"-thick plates were received in FY14. The lot numbers of the two plates are "67-7" and "67-9". They were hot forged, and annealed at $1150^{\circ} \mathrm{C}$ for $1 \mathrm{~h}$ under a reducing atmosphere, and then water quenched.

- Alloy 709-05 (CarTech Heat 011502) was also made by Carpenter Technology. It was annealed for $2 \mathrm{~h}$ at $1100^{\circ} \mathrm{C}$, and then water quenched.

The chemical composition and heat treatment conditions of the three heats of Alloy 709 are given in Tables 1 and 2, respectively.

Four heats of optimized G92 were examined, i.e. Opt. G92-3, Opt. G92-4, Opt. G92-4T, and Opt. G92-8T. Commercial G92 (Generic Heat No. G92-0) was included to provide the baseline data and compare with Opt. G92. All the materials were provided by the Oak Ridge National Laboratory (ORNL).

- Opt. G92-3 (Heat 1105364201, Generic Heat No. G92-3) was made by vacuum-induction melting (VIM) by Sophisticated Alloys, and was in 1"-thick plate form. It was heat treated at $1177^{\circ} \mathrm{C}$ for $4 \mathrm{~h}$, hot-forged/rolled, air cooled, followed by normalization at $1080^{\circ} \mathrm{C}$ for $1 \mathrm{~h}$, air cooling, and tempering at $750^{\circ} \mathrm{C}$ for $2 \mathrm{~h}$, and air cooling.

- Opt. G92-4 (Heat 011364, Generic Heat No. G92-4) was made by VIM and electroslag remelting (ESR) by Carpenter Technology. It was in 3"-thick plate form. It was normalized at $1150^{\circ} \mathrm{C}$ for $1 \mathrm{~h}$ and water quenched, followed by hot forging at $1050^{\circ} \mathrm{C}$ and water quench, and tempered at $750^{\circ} \mathrm{C}$ for $1 \mathrm{~h}$ and air cooled.

- Opt. G92-4T (Heat 011364, Generic Heat No. G92-4T) was made by VIM and ESR by Carpenter Technology. It was in 1 "-thick plate form. The plate was normalized at $1150^{\circ} \mathrm{C}$ for $1 \mathrm{~h}$, followed by hot forging at $1050^{\circ} \mathrm{C}$ and water quench, and tempered at $750^{\circ} \mathrm{C}$ for $1 \mathrm{~h}$ and air cooled.

- Opt. G92-8T was produced via VIM route and was in 1.6"-thick plate form. It was hot forged from $1130^{\circ} \mathrm{C}$ and held at $1130^{\circ} \mathrm{C}$ for $0.5 \mathrm{~h}$ and water quenched, followed by tempering at $600^{\circ} \mathrm{C}$ for $1 \mathrm{~h}$ at $600^{\circ} \mathrm{C}$ and air cooled. It was re-tempered at $750^{\circ} \mathrm{C}$ for $4 \mathrm{~h}$ and air cooled.

- G92-0 was in 1"-thick plate form. It was normalized at $1050^{\circ} \mathrm{C}$ and tempered at $750^{\circ} \mathrm{C}$ for 2 $\mathrm{h}$ and air cooled.

The chemical composition and heat treatment conditions of Opt. G92 and commercial G92 are given in Tables 3 and 4, respectively. 
Table 1. Chemical composition of Alloy 709 (in wt\%)

\begin{tabular}{|c|c|c|c|c|c|c|c|c|c|c|c|c|c|c|c|}
\hline $\begin{array}{l}\text { Generic } \\
\text { Heat No. }\end{array}$ & Heat & $\mathrm{Fe}$ & $\mathrm{C}$ & $\mathrm{Mn}$ & $\mathrm{P}$ & $\mathrm{S}$ & $\mathrm{Si}$ & $\mathrm{Ni}$ & $\mathrm{Cr}$ & Mo & $\mathrm{B}$ & $\mathrm{Ti}$ & $\mathrm{Nb}$ & $\mathrm{N}$ & $\mathrm{Al}$ \\
\hline 709-01 & 120113806 & Bal & 0.05 & 1.0 & $<0.01$ & $<0.01$ & 0.39 & 24.5 & 20.9 & 1.5 & 0.003 & 0.07 & 0.23 & 0.19 & - \\
\hline $709-02$ & 011367 & Bal & 0.078 & 0.90 & $<0.005$ & $<0.001$ & 0.30 & 25.03 & 20.04 & 1.51 & 0.003 & $<0.01$ & 0.26 & 0.17 & - \\
\hline 709-05 & 011502 & Bal & 0.063 & 0.88 & $<0.005$ & $<0.001$ & 0.28 & 25.00 & 19.69 & 1.46 & 0.0022 & $<0.01$ & 0.23 & 0.14 & - \\
\hline
\end{tabular}

Table 2. Heat treatment conditions of Alloy 709

\begin{tabular}{lll}
\hline Generic Heat No. & Heat & Heat treatment \\
\hline $709-01$ & 120113806 & Anneal at $1150^{\circ} \mathrm{C}$ for 30 min, water quenched \\
\hline $709-02$ & 011367 & Anneal at $1050^{\circ} \mathrm{C}$ for 30 min, water quenched \\
\hline $709-05$ & 011502 & Anneal at $1100^{\circ} \mathrm{C}$ for 120 min, water quenched \\
\hline
\end{tabular}


Table 3. Chemical composition of Opt. G92 and G92 (in wt\%)

\begin{tabular}{llccccccccccccc}
\hline \multirow{2}{*}{ Alloy } & $\begin{array}{l}\text { Generic } \\
\text { Heat No. }\end{array}$ & Heat & $\mathrm{Fe}$ & $\mathrm{C}$ & $\mathrm{Cr}$ & $\mathrm{Mn}$ & $\mathrm{Mo}$ & $\mathrm{N}$ & $\mathrm{Nb}$ & $\mathrm{Ni}$ & $\mathrm{Si}$ & $\mathrm{Ti}$ & $\mathrm{V}$ & $\mathrm{W}$ \\
\hline Opt.G92 & G92-3 & $11053642-1$ & $\mathrm{Bal}$ & 0.05 & 9 & 0.5 & 0.5 & 0.05 & 0.1 & 0.1 & 0.2 & - & 0.2 & 1.9 \\
\hline Opt.G92 & G92-4 & 011364 & $\mathrm{Bal}$ & 0.09 & 8.74 & 0.36 & 0.36 & 0.029 & 0.06 & 0.12 & 0.01 & 0.001 & 0.19 & 1.88 \\
\hline Opt.G92 & G92-4T & 011364 & Bal & 0.09 & 8.74 & 0.36 & 0.36 & 0.029 & 0.06 & 0.12 & 0.01 & 0.001 & 0.19 & 1.88 \\
\hline Opt. G92 & G92-8T & 011448 & Bal & 0.091 & 8.81 & 0.4 & 0.36 & 0.046 & 0.08 & 0.12 & 0.1 & 0.005 & 0.18 & 1.78 \\
\hline G92 & G92-0 & - & Bal & 0.11 & 9.1 & 0.46 & 0.43 & 0.057 & 0.08 & 0.06 & 0.03 & - & 0.20 & 1.84 \\
\hline
\end{tabular}

Table 4. Heat treatment conditions of Opt. G92 and G92

\begin{tabular}{llcc}
\hline Alloy & $\begin{array}{l}\text { Generic } \\
\text { Heat No. }\end{array}$ & Heat & Heat treatment \\
\hline Opt.G92 & G92-3 & $11053642-1$ & $1177^{\circ} \mathrm{C} / 4 \mathrm{~h}+$ hot-forging/rolling $+1080^{\circ} \mathrm{C} / 1 \mathrm{~h} / \mathrm{AC}{ }^{(1)}+750^{\circ} \mathrm{C} / 2 \mathrm{~h} / \mathrm{AC}$ \\
\hline Opt.G92 & G92-4 & 011364 & $1150^{\circ} \mathrm{C} / 1 \mathrm{~h} / \mathrm{WQ}{ }^{(2)}+750^{\circ} \mathrm{C} / 1 \mathrm{~h} / \mathrm{AC}$ \\
\hline Opt.G92 & G92-4T & 011364 & $1150^{\circ} \mathrm{C} / 1 \mathrm{~h} / \mathrm{WQ}+$ Hot Forging at $1050^{\circ} \mathrm{C} / \mathrm{WQ}+750^{\circ} \mathrm{C} / 1 \mathrm{~h} / \mathrm{AC}$ \\
\hline Opt. G92 & G92-8T & 011448 & Hot forging at $1130^{\circ} \mathrm{C}+1130^{\circ} \mathrm{C} / 0.5 \mathrm{~h} / \mathrm{WQ}+600^{\circ} \mathrm{C} / 1 \mathrm{~h} / \mathrm{AC}+750^{\circ} \mathrm{C} / 4 \mathrm{~h} / \mathrm{AC}$ \\
\hline G92 & G92-0 & - & Normalized at $\sim 1050^{\circ} \mathrm{C}$ and tempered at $750^{\circ} \mathrm{C} / 2 \mathrm{~h} / \mathrm{AC}$ \\
\hline
\end{tabular}

${ }^{(1)} \mathrm{AC}$ - air cooling; ${ }^{(2)} \mathrm{WQ}$ - water quenching 
Subsize sheet-type tensile specimens with extended grip sections (Fig. 1) were used in thermal aging experiments and tensile tests. The extended grip sections were designed for microstructural characterization and tensile test to be conducted on the same sample to minimize data scatter from specimen variations. The tensile specimens were electrical-dischargemachined with the gage parallel to the rolling direction. The tensile specimen has nominal gage dimensions of $7.62 \times 1.52 \times 0.76 \mathrm{~mm}$.

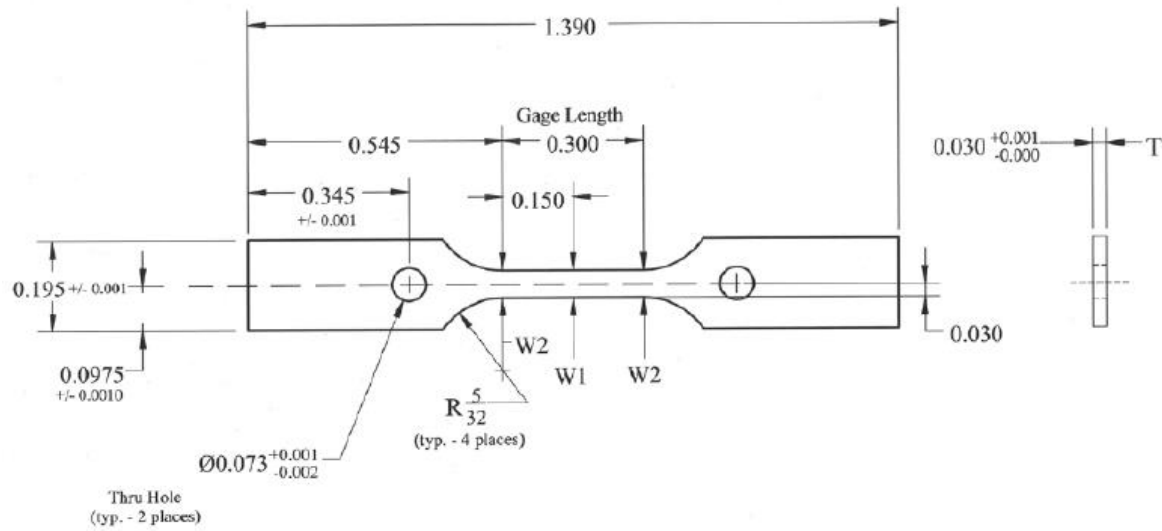

(a)

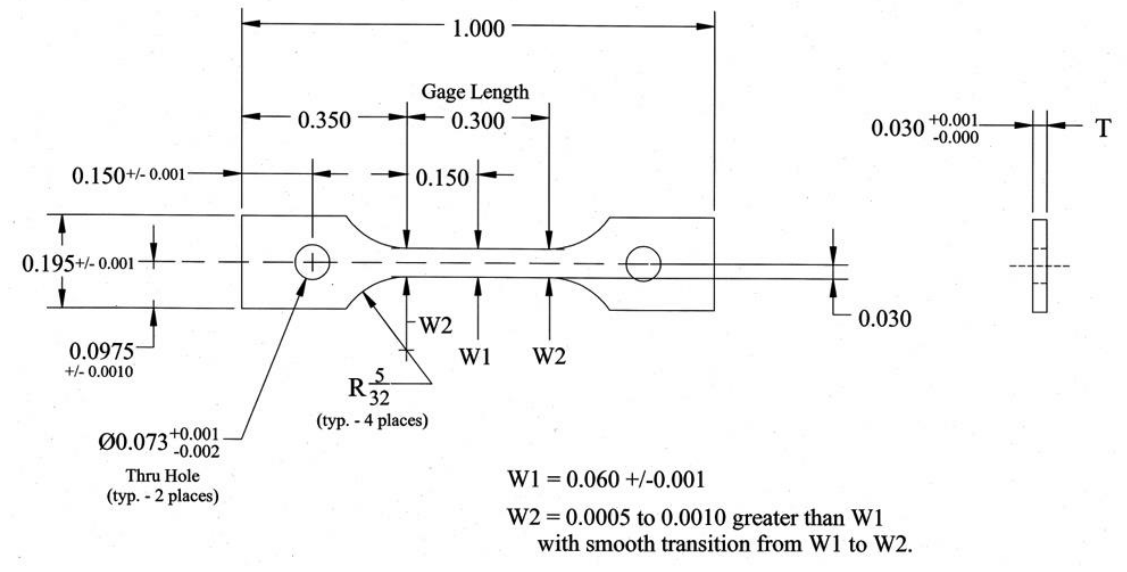

(b)

Figure 1. Schematic drawing of subsize sheet-type tensile specimens used for thermal aging tests (a) the extended-grip tensile specimen used for microstructural characterization and tensile tests and (b) the specimen used for tensile tests.

\subsection{Thermal aging experiments}

Thermal aging experiments were performed at 550,600 , and $650^{\circ} \mathrm{C}$ for various exposure times to examine the effect of thermal aging on tensile properties and microstructure. Each tensile specimen was wrapped in Ta foil and encapsulated in a quartz tube under vacuum (shown in Fig. 2(a)). Encapsulated specimens were loaded in an air furnace (Fig. 2(b)) that was heated to the target temperature for an extended period. 


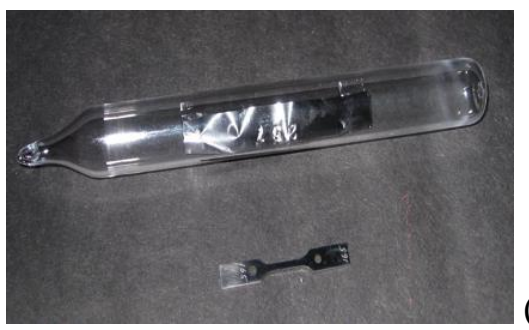

(a)

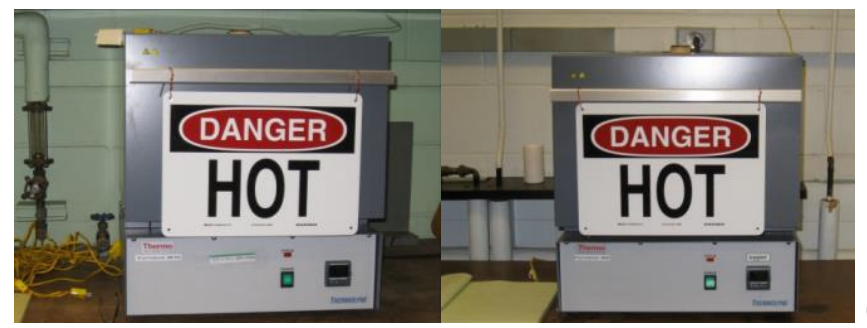

(b)

Figure 2. Thermal aging experiment (a) vacuum-encapsulated specimens and (b) hightemperature furnaces used for thermal aging tests.

Table 5 provides the total exposure times at different temperatures for various heats of Alloy 709, Opt. G92 and G92.

Table 5. Total thermal exposure times at 550, 600, and $650^{\circ} \mathrm{C}$ for Alloy 709, Opt. G92 and G92.

\begin{tabular}{|c|c|c|c|c|}
\hline Alloy & Heat No. & $\begin{array}{c}\text { Total Exposure } \\
\text { Time at } 550^{\circ} \mathrm{C}(\mathrm{h})\end{array}$ & $\begin{array}{c}\text { Total Exposure } \\
\text { Time at } 600^{\circ} \mathrm{C}(\mathrm{h})\end{array}$ & $\begin{array}{c}\text { Total Exposure } \\
\text { Time at } 650^{\circ} \mathrm{C}(\mathrm{h})\end{array}$ \\
\hline Alloy 709 & $709-01$ & - & - & 40,071 \\
\hline Alloy 709 & $709-02$ & 8,118 & 15,700 & 20,105 \\
\hline Alloy 709 & $709-05$ & - & - & 9,761 \\
\hline Opt. G92 & G92-3 & 34,132 & 29,594 & 21,480 \\
\hline Opt. G92 & G92-4 & 8,843 & 13,748 & 5,284 \\
\hline Opt. G92 & G92-4T & 8,144 & 13,748 & 5,284 \\
\hline Opt. G92 & G92-8T & - & 3,695 & 5,284 \\
\hline G92 & G92-0 & 19,926 & 14,979 & 36,061 \\
\hline
\end{tabular}

\subsection{High temperature tensile tests}

Tensile specimens were tested under uniaxial tension in an air furnace. Figure 3 shows a setup for high temperature tensile tests in air at the Argonne National Laboratory. Tensile tests were performed in an electromechanical testing system equipped with a three-zone air furnace. The applied load was recorded by a load cell; the specimen displacement was measured by the crosshead extension. The engineering tensile properties were determined from analysis of load versus displacement data files. As-received specimens were tested at a range of temperatures of $20-650^{\circ} \mathrm{C}$. Thermally-aged specimens were tested at the thermal aging temperature. All the tests were conducted at a nominal strain rate, $0.001 \mathrm{~s}^{-1}$. 


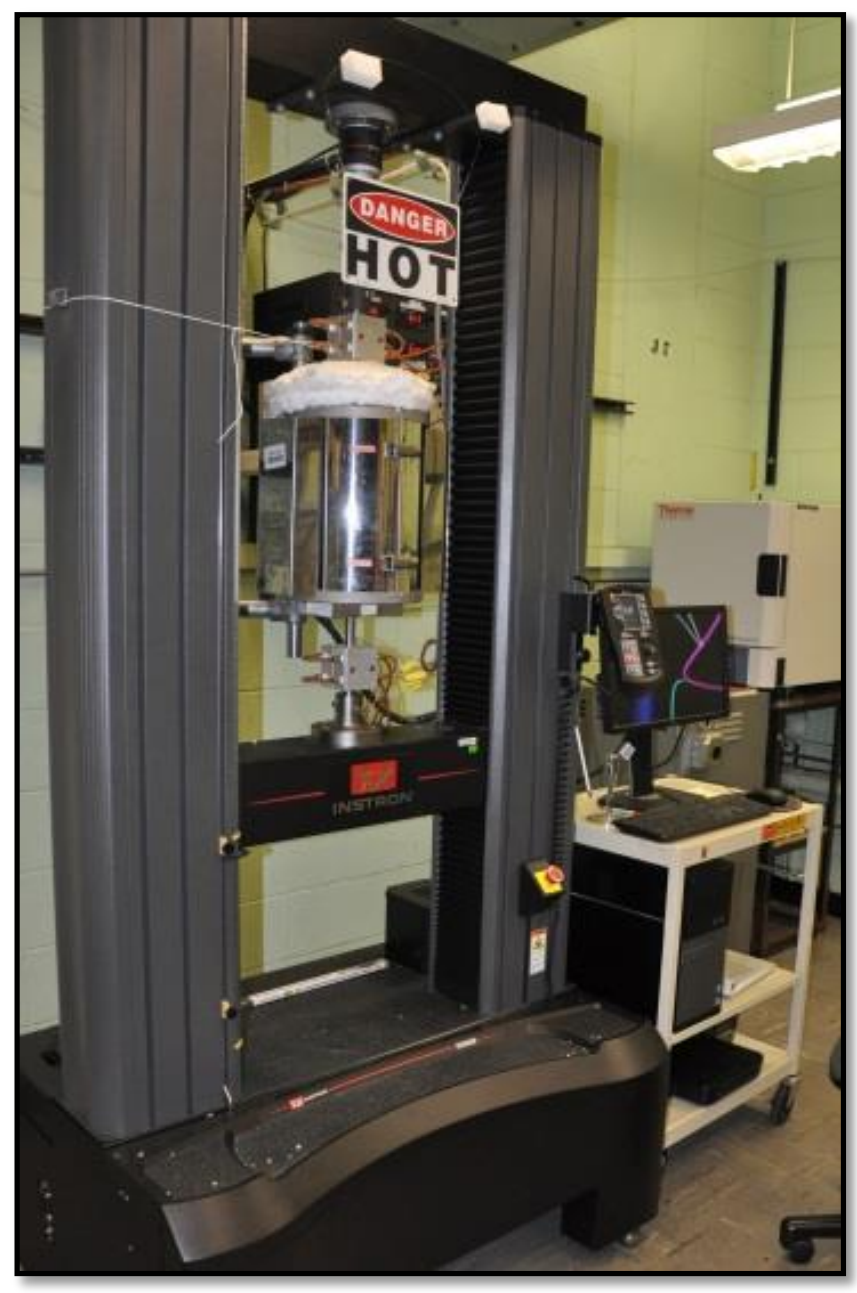

Figure 3. Experimental setup for high temperature tensile tests. 


\section{Results}

\subsection{Effect of thermal aging on tensile properties of Alloy 709}

Figures 4-6 show the yield stress, the ultimate tensile strength, the uniform elongation, and the total elongation as a function of aging time for Alloy 709 thermally aged at 550,600, and $650^{\circ} \mathrm{C}$, respectively. The as-received condition is plotted as " $1 \mathrm{~h}$ - exposure" for convenience. Table 6 summarizes the tensile property data of thermally-aged Alloy 709. Note that a few data exist for thermal aging at $550-600^{\circ} \mathrm{C}$, and for one heat only, 709-02.

Thermal aging at $550^{\circ} \mathrm{C}$ has minimal effect on the tensile properties for times $<10,000 \mathrm{~h}$, as shown in Fig. 4. A slight increase in the yield stress and a decrease in the ultimate tensile strength (UTS) was observed after thermal aging at $600^{\circ} \mathrm{C}$ for $\sim 15,000 \mathrm{~h}$, shown in Fig. 5. The effect of thermal aging on the tensile properties of Alloy 709 is more pronounced at $650^{\circ} \mathrm{C}$. An increase in the yield stress and a decrease in the UTS are accompanied by the reductions in uniform and total elongations, as shown in Fig. 6 . The yield stress was increased by $\sim 34 \%$, the UTS was reduced by $\sim 9 \%$, and the uniform and total elongations were reduced by $\sim 50 \%$ and $\sim 36 \%$, respectively after aging for $\sim 20,000 \mathrm{~h}$ at $650^{\circ} \mathrm{C}$. The effect of thermal aging on tensile properties showed little variations among three heats of Alloy 709 .
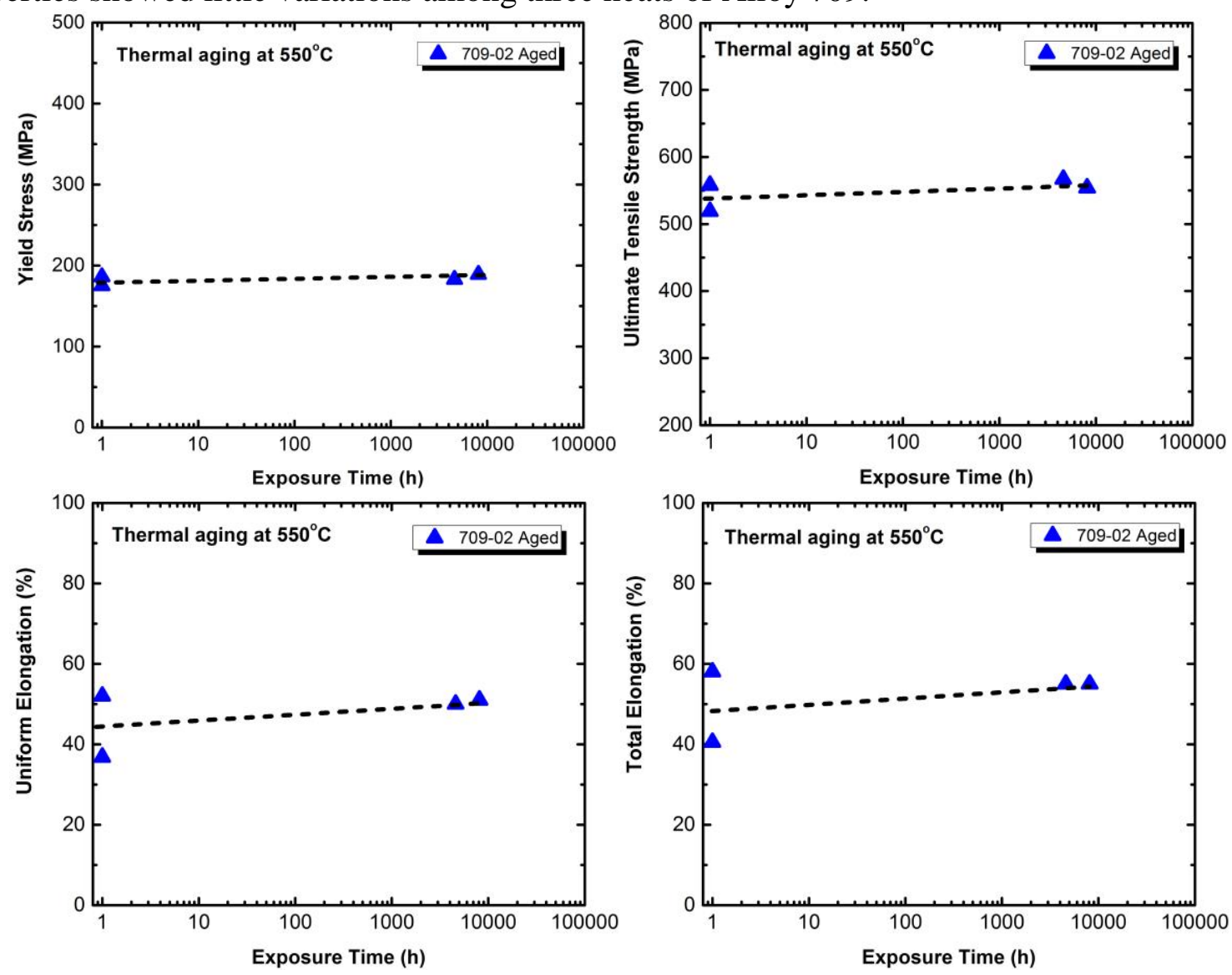

Figure 4. The yield stress, ultimate tensile strength, uniform elongation and total elongation as a function of exposure time for Alloy 709 tensile tested at $550^{\circ} \mathrm{C}$ after thermal aging at $550^{\circ} \mathrm{C}$. 

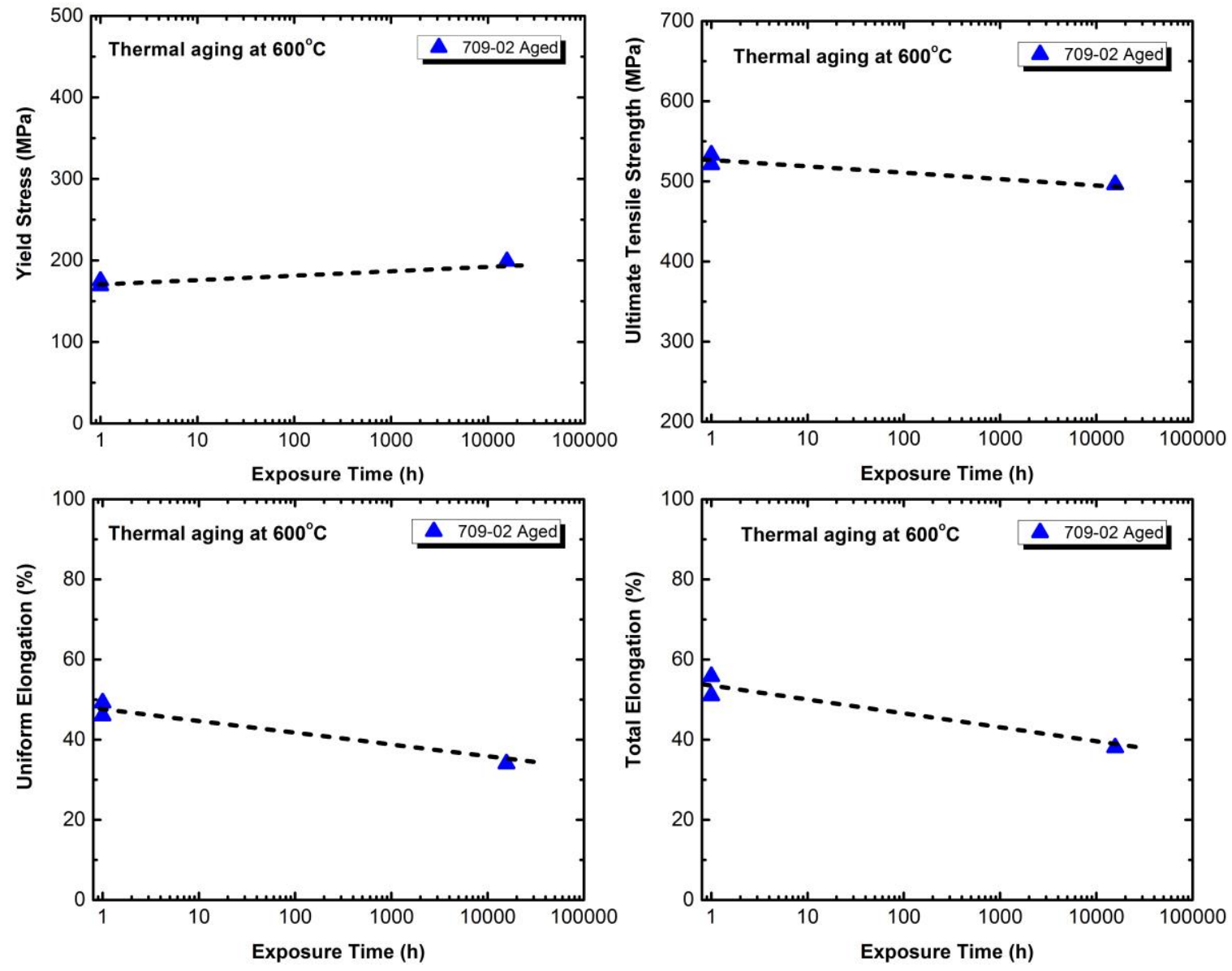

Figure 5. The yield stress, ultimate tensile strength, uniform elongation and total elongation as a function of exposure time for Alloy 709 tensile tested at $600^{\circ} \mathrm{C}$ after thermal aging at $600^{\circ} \mathrm{C}$. 

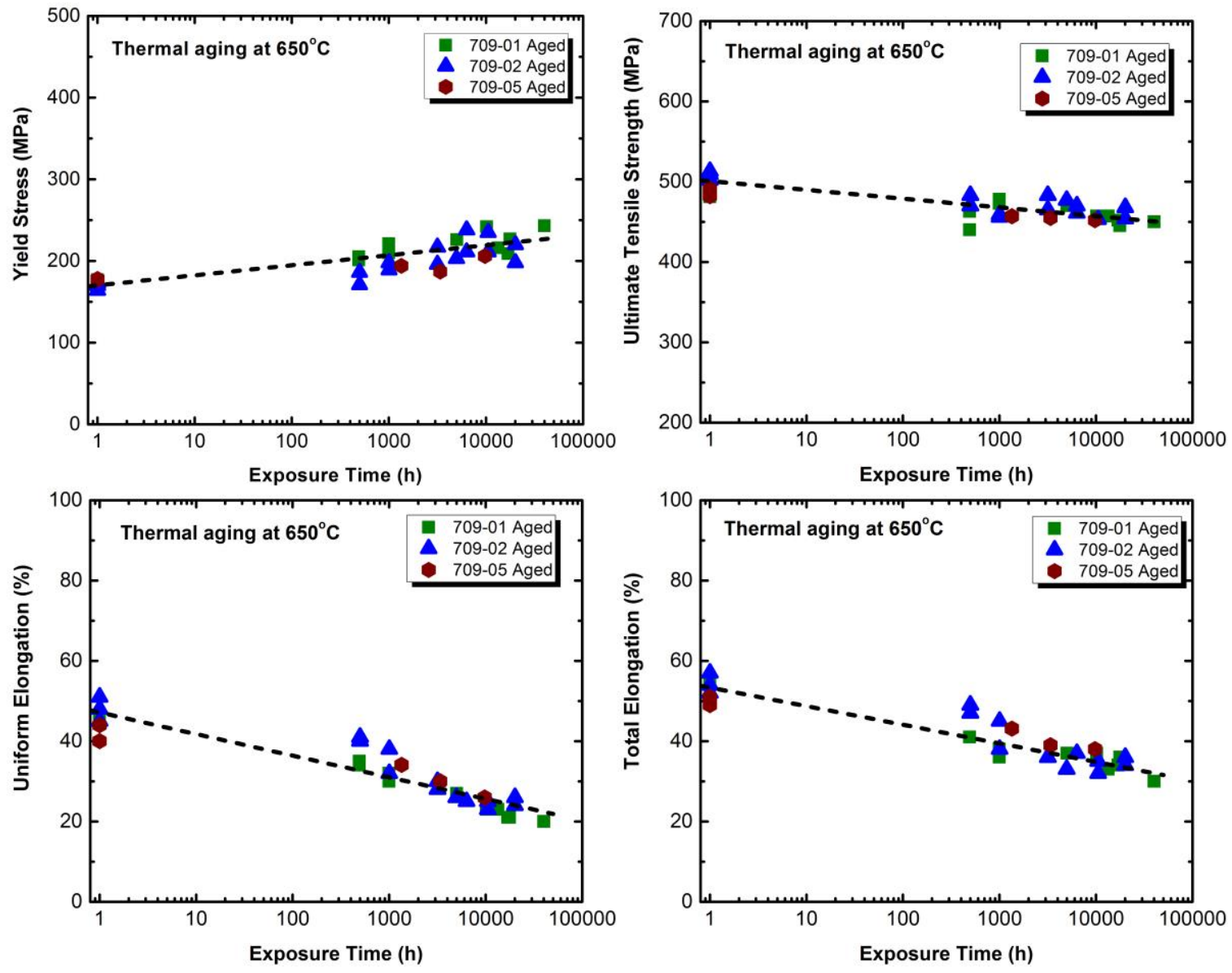

Figure 6. The yield stress, ultimate tensile strength, uniform elongation and total elongation as a function of exposure time for Alloy 709 tensile tested at $650^{\circ} \mathrm{C}$ after thermal aging at $650^{\circ} \mathrm{C}$. 
Table 6. Tensile properties of thermally-aged Alloy 709.

\begin{tabular}{|c|c|c|c|c|c|c|c|}
\hline Heat No. & Aging $\mathrm{T}\left({ }^{\circ} \mathrm{C}\right)$ & Aging time (h) & Test $\mathrm{T}\left({ }^{\circ} \mathrm{C}\right)$ & YS (MPa) & UTS (MPa) & $\mathrm{UE}(\%)$ & TE (\%) \\
\hline $709-01$ & - & 0 & 650 & 177 & 481 & 46 & 50 \\
\hline 709-01 & - & 0 & 650 & 173 & 502 & 46 & 54 \\
\hline 709-01 & 650 & 491 & 650 & 205 & 463 & 35 & 41 \\
\hline 709-01 & 650 & 491 & 650 & 201 & 440 & 34 & 41 \\
\hline 709-01 & 650 & 1,000 & 650 & 221 & 473 & 30 & 36 \\
\hline 709-01 & 650 & 1,000 & 650 & 210 & 478 & 32 & 38 \\
\hline $709-01$ & 650 & 5,021 & 650 & 226 & 470 & 27 & 37 \\
\hline $709-01$ & 650 & 10,197 & 650 & 242 & 457 & 23 & 37 \\
\hline $709-01$ & 650 & 13,391 & 650 & 216 & 457 & 23 & 32.5 \\
\hline 709-01 & 650 & 16,931 & 650 & 209 & 452 & 21 & 34 \\
\hline $709-01$ & 650 & 17,727 & 650 & 227 & 445 & 21 & 36 \\
\hline 709-01 & 650 & 40,071 & 650 & 243 & 450 & 20 & 30 \\
\hline $709-02$ & 550 & 0 & 550 & 186 & 558 & 52 & 58 \\
\hline $709-02$ & 550 & 0 & 550 & 175 & 519 & 36.8 & 40.5 \\
\hline $709-02$ & 550 & 4,590 & 550 & 183 & 567 & 50 & 55 \\
\hline $709-02$ & 550 & 8,118 & 550 & 189 & 554 & 51 & 55 \\
\hline $709-02$ & - & 0 & 600 & 169 & 521 & 46 & 51 \\
\hline 709-02 & - & 10 & 600 & 175 & 533 & 49.2 & 55.8 \\
\hline 709-02 & 600 & 15,700 & 600 & 199 & 496 & 34 & 38 \\
\hline 709-02 & - & 0 & 650 & 170 & 509 & 45 & 51.5 \\
\hline 709-02 & - & 0 & 650 & 173 & 513 & 51 & 57 \\
\hline 709-02 & - & 0 & 650 & 164 & 502 & 48 & 54 \\
\hline 709-02 & 650 & 500 & 650 & 171 & 470 & 40 & 47 \\
\hline 709-02 & 650 & 500 & 650 & 186 & 483 & 41 & 49 \\
\hline 709-02 & 650 & 1,003 & 650 & 189 & 456 & 38 & 45 \\
\hline 709-02 & 650 & 1,003 & 650 & 198 & 459 & 32 & 38 \\
\hline 709-02 & 650 & 3,171 & 650 & 217 & 483 & 30 & 36 \\
\hline 709-02 & 650 & 3,171 & 650 & 196 & 465 & 28 & 35.5 \\
\hline 709-02 & 650 & 4,971 & 650 & 203 & 477 & 26 & 32.5 \\
\hline 709-02 & 650 & 6,331 & 650 & 238 & 470 & 25 & 36.5 \\
\hline 709-02 & 650 & 6,331 & 650 & 211 & 461 & 25 & 36.5 \\
\hline 709-02 & 650 & 10,537 & 650 & 211 & 453 & 25 & 35 \\
\hline 709-02 & 650 & 10,537 & 650 & 235 & 453 & 23 & 32 \\
\hline 709-02 & 650 & 20,105 & 650 & 198 & 454 & 24 & 34 \\
\hline 709-02 & 650 & 20,105 & 650 & 220 & 468 & 25.6 & 35.7 \\
\hline 709-05 & - & 0 & 650 & 177 & 491 & 40 & 49 \\
\hline 709-05 & - & 0 & 650 & 178 & 482 & 44 & 51 \\
\hline 709-05 & 650 & 1,345 & 650 & 194 & 457 & 34.1 & 43.1 \\
\hline 709-05 & 650 & 3,384 & 650 & 187 & 455 & 30 & 39 \\
\hline 709-05 & 650 & 9,761 & 650 & 206 & 452 & 26 & 38 \\
\hline
\end{tabular}




\subsection{Effect of thermal aging on tensile properties of optimized G92}

The effects of thermal aging on the tensile properties of optimized G92 are illustrated in Figs. $8-10$, where the yield stress, the ultimate tensile strength (UTS), the uniform elongation, and the total elongation are plotted as a function of aging time for optimized G92 thermally aged at 550,600 , and $650^{\circ} \mathrm{C}$, respectively. The data of the thermally-aged G92 specimens are included in Figs. 8-10 as the baseline data to compare with the performance of optimized G92, as well as the data of the sodium-exposed optimized G92 and conventional G92. The tensile property data of thermally-aged optimized G92 and commercial G92 are summarized in Table 7.

Thermal aging at $550-650^{\circ} \mathrm{C}$ decreased the yield stress and the ultimate tensile strength of optimized G92. The effect of thermal aging was stronger at higher temperatures and longer exposure times. The effect of thermal aging on tensile strength became evident after $\sim 10,000 \mathrm{~h}$ at $550^{\circ} \mathrm{C}, \sim 1,000 \mathrm{~h}$ at $600^{\circ} \mathrm{C}$, and $<1,000 \mathrm{~h}$ at $650^{\circ} \mathrm{C}$. The aging-induced reduction in tensile strength was much more pronounced at $650^{\circ} \mathrm{C}$ than at temperatures of $550-600^{\circ} \mathrm{C}$. The reductions in tensile strength resulted from thermal aging at $650^{\circ} \mathrm{C}$ varied among different heats of optimized G92. Heats of Opt. G92-3 and Opt. G92-8T have the highest UTS in the asreceived condition. The UTS of these two heats was reduced by $\sim 30 \%$ after thermal exposure at $650^{\circ} \mathrm{C}$ for 5,000 h. Heats of Opt. G92-4 and Opt. G92-4T have the lowest UTS prior to thermal exposures, and their UTS values were reduced by $\sim 10 \%$ after thermal exposure at $650^{\circ} \mathrm{C}$ for $5,000 \mathrm{~h}$. While the commercial G92 has the moderate UTS compared to various heats of optimized G92, its UTS was decreased by $\sim 15 \%$ from thermal exposures at $650^{\circ} \mathrm{C}$. Ductility of thermally-aged optimized G92 and commercial G92 remained adequate with $>15 \%$ of total elongation.

Sodium exposures at 550 and $600^{\circ} \mathrm{C}$ caused virtually no additional effect on the tensile strength and the elongations when compared with the thermally-aged specimens of optimized and commercial $\mathrm{G} 92$, while sodium exposures at $650^{\circ} \mathrm{C}$ have a much stronger effect than thermal exposures alone under comparable temperature and time conditions for all heats of optimized G92 and commercial G92. 

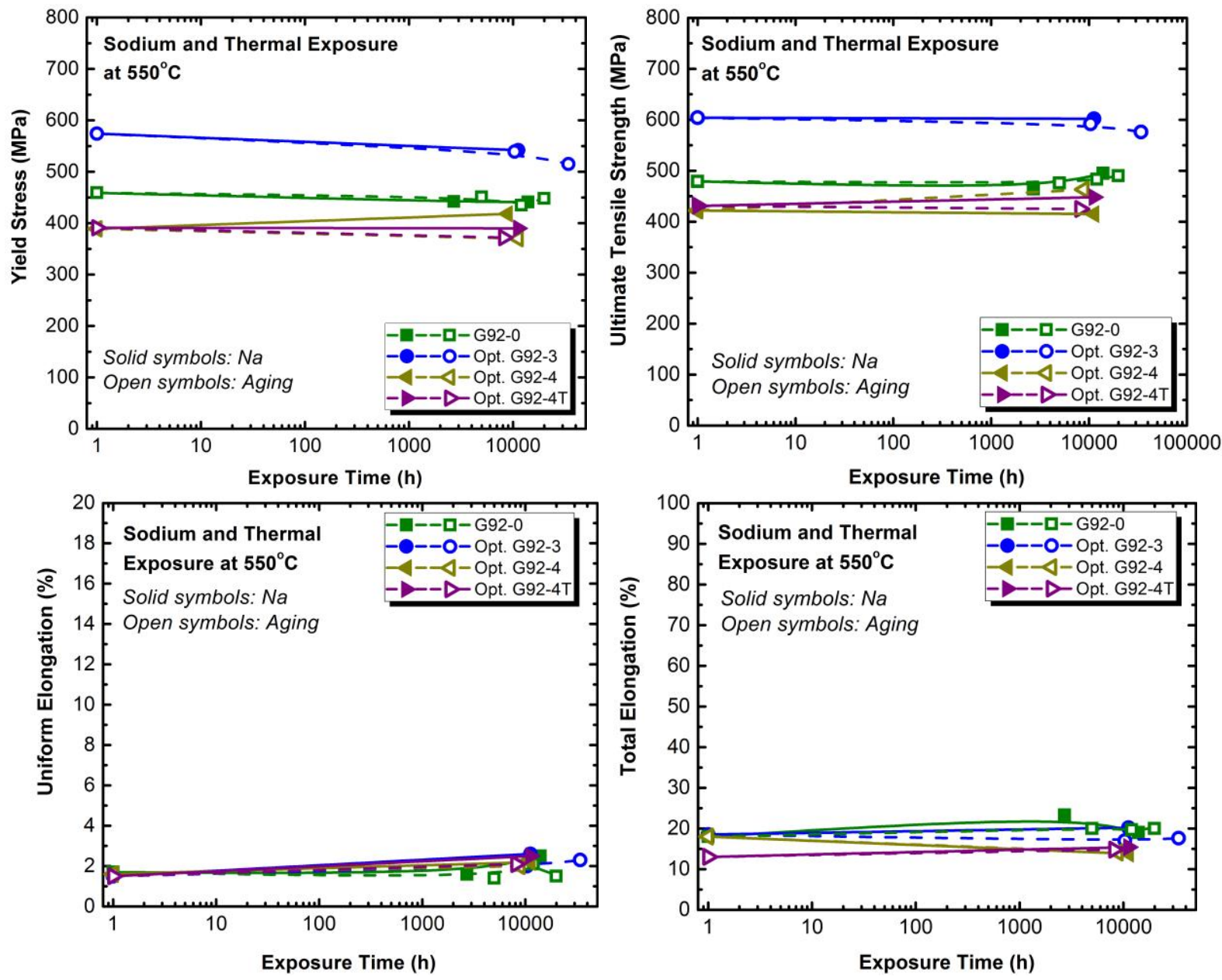

Figure 7. The yield stress, ultimate tensile strength, uniform elongation and total elongation as a function of exposure time for Opt. G92 and G92 tensile tested at $550^{\circ} \mathrm{C}$ after thermal aging at $550^{\circ} \mathrm{C}$. 

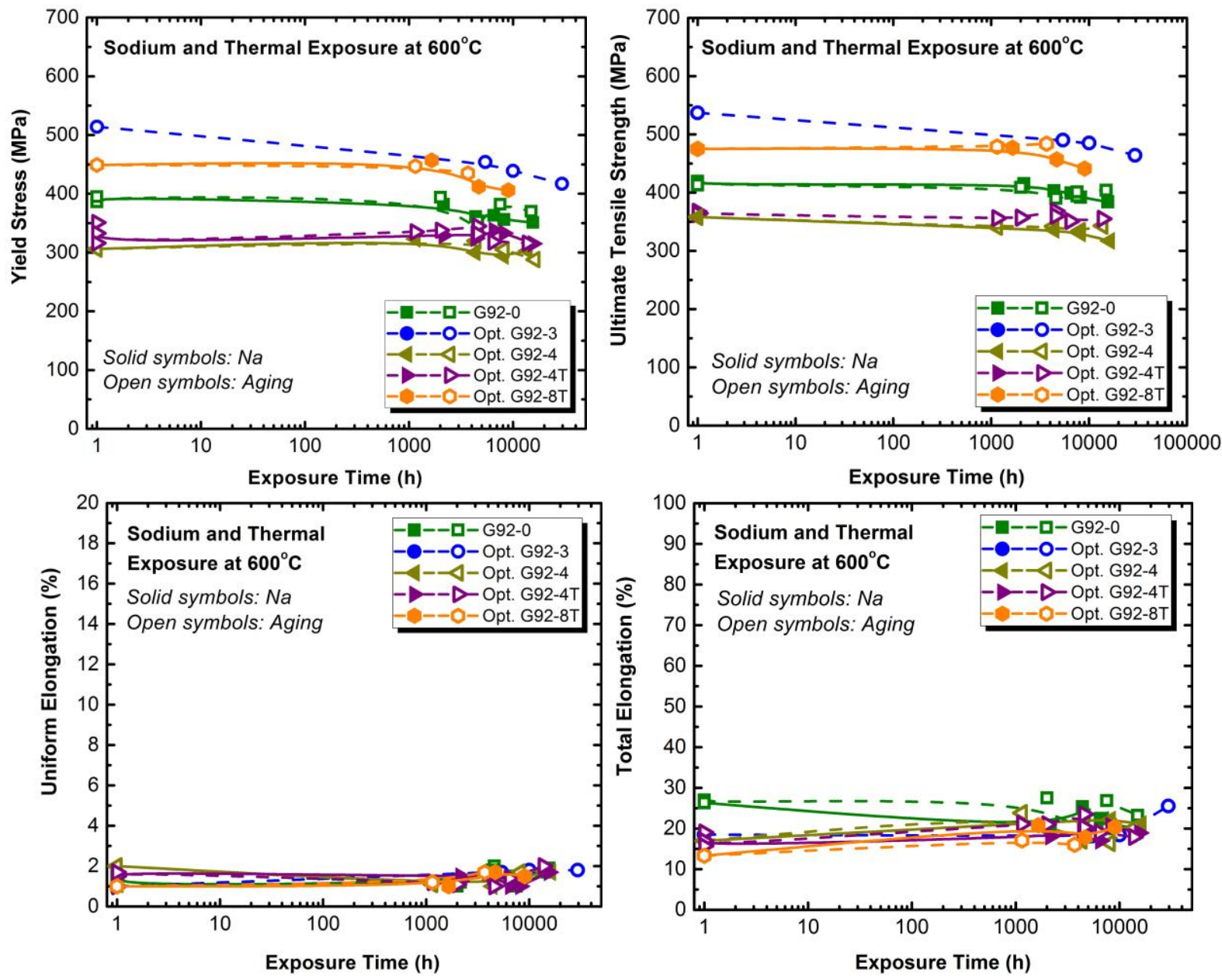

Figure 8. The yield stress, ultimate tensile strength, uniform elongation and total elongation as a function of exposure time for Opt. G92 and G92 tensile tested at $600^{\circ} \mathrm{C}$ after thermal aging at $600^{\circ} \mathrm{C}$. 

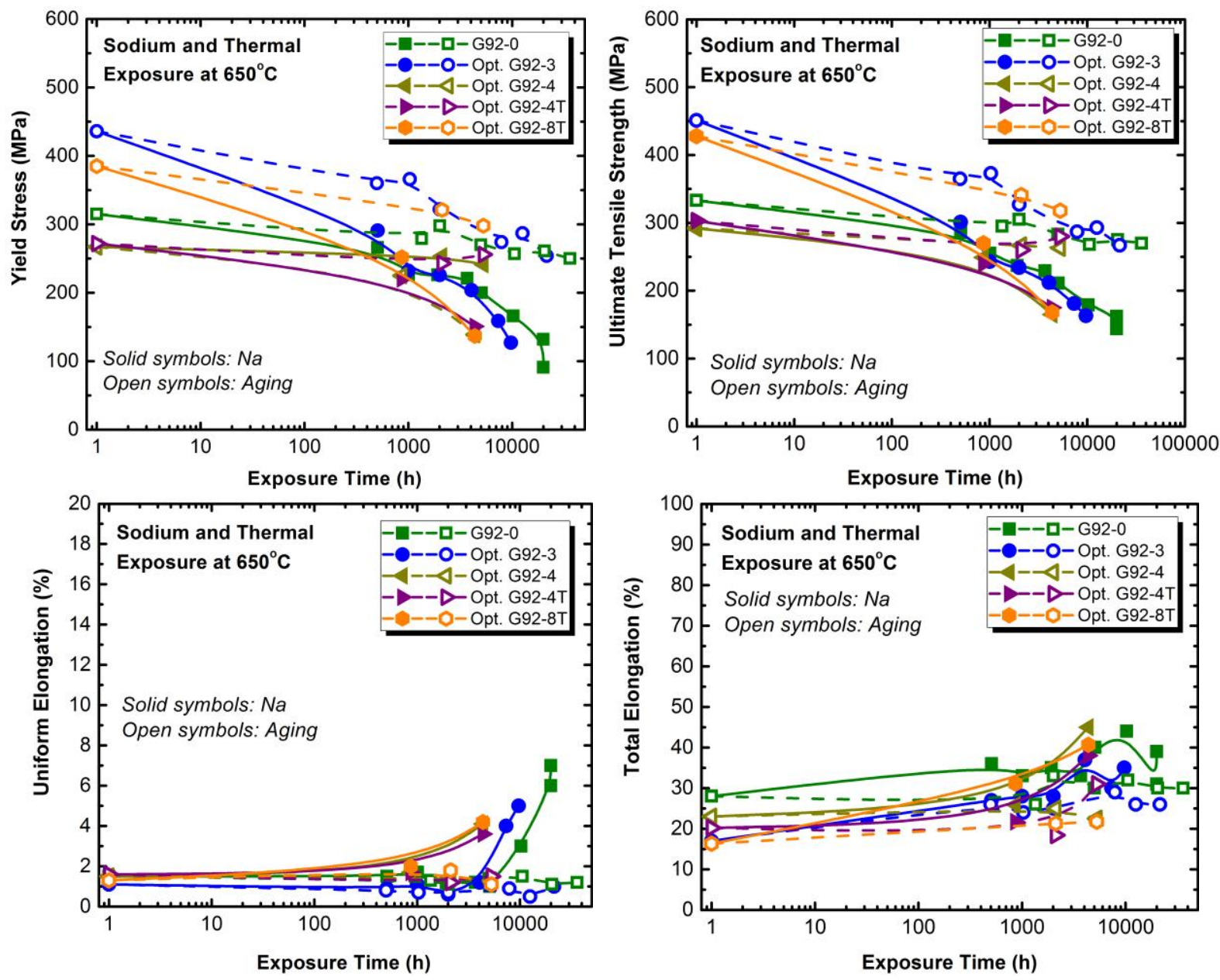

Figure 9. The yield stress, ultimate tensile strength, uniform elongation and total elongation as a function of exposure time for Opt. G92 and G92 tensile tested at $650^{\circ} \mathrm{C}$ after thermal aging at $650^{\circ} \mathrm{C}$. 
Table 7. Tensile properties of thermally-aged Opt. G92 and G92

\begin{tabular}{|c|c|c|c|c|c|c|c|}
\hline Heat No. & Aging $\mathrm{T}\left({ }^{\circ} \mathrm{C}\right)$ & Aging time (h) & Test $\mathrm{T}\left({ }^{\circ} \mathrm{C}\right)$ & YS (MPa) & UTS (MPa) & UE (\%) & TE (\%) \\
\hline Opt. G92-3 & - & 0 & 550 & 574 & 604 & 1.5 & 18.5 \\
\hline Opt. G92-3 & 550 & 10,353 & 550 & 539 & 592 & 2.0 & 17 \\
\hline Opt. G92-3 & 550 & 34,132 & 550 & 515 & 576 & 2.3 & 17.6 \\
\hline Opt. G92-3 & - & 0 & 600 & 514 & 537 & 1 & 18.5 \\
\hline Opt. G92-3 & 600 & 5,417 & 600 & 454 & 490 & 1.7 & 18.1 \\
\hline Opt. G92-3 & 600 & 10,007 & 600 & 439 & 485 & 1.8 & 18.4 \\
\hline Opt. G92-3 & 600 & 29,594 & 600 & 417 & 464 & 1.8 & 25.5 \\
\hline Opt. G92-3 & - & 0 & 650 & 436 & 451 & 1.1 & 17 \\
\hline Opt. G92-3 & 650 & 499 & 650 & 360 & 365 & 0.8 & 26 \\
\hline Opt. G92-3 & 650 & 1,033 & 650 & 366 & 373 & 0.7 & 24 \\
\hline Opt. G92-3 & 650 & 2,011 & 650 & 322 & 327 & 0.7 & 25 \\
\hline Opt. G92-3 & 650 & 7,891 & 650 & 274 & 287 & 0.9 & 29 \\
\hline Opt. G92-3 & 650 & 12,574 & 650 & 287 & 293 & 0.5 & 26 \\
\hline Opt. G92-3 & 650 & 21,480 & 650 & 254 & 267 & 1 & 26 \\
\hline Opt. G92-4 & - & 0 & 550 & 389 & 422 & 1.6 & 18 \\
\hline Opt. G92-4 & 550 & 8,843 & 550 & 418 & 463 & 2.0 & 14.1 \\
\hline Opt. G92-4 & - & 0 & 600 & 306 & 358 & 2 & 17 \\
\hline Opt. G92-4 & 600 & 1,152 & 600 & 323 & 341 & 1.1 & 23.8 \\
\hline Opt. G92-4 & 600 & 4,344 & 600 & 300 & 342 & 1.5 & 17 \\
\hline Opt. G92-4 & 600 & 8,110 & 600 & 294 & 334 & 1.7 & 16.4 \\
\hline Opt. G92-4 & 600 & 13,748 & 600 & 303 & 343 & 1.8 & 20.1 \\
\hline Opt. G92-4 & - & 1 & 650 & 267 & 292 & 1.5 & 23.0 \\
\hline Opt. G92-4 & - & 1 & 650 & & & & \\
\hline Opt. G92-4 & 650 & 2,116 & 650 & 254 & 267 & 1.4 & 25.0 \\
\hline Opt. G92-4 & 650 & 5,284 & 650 & 241 & 263 & 1.3 & 22.5 \\
\hline Opt. G92-4T & - & 0 & 550 & 391 & 431 & 1.5 & 13 \\
\hline Opt. G92-4T & 550 & 8,144 & 550 & 372 & 425 & 2.1 & 14.8 \\
\hline Opt. G92-4T & - & 0 & 600 & 351 & 365 & 1 & 19 \\
\hline Opt. G92-4T & - & 0 & 600 & 333 & 367 & 1.5 & 17 \\
\hline Opt. G92-4T & - & 0 & 600 & 316 & 363 & 1.7 & 15.7 \\
\hline Opt. G92-4T & 600 & 1,152 & 600 & 335 & 356 & 1.2 & 21.1 \\
\hline Opt. G92-4T & 600 & 2,009 & 600 & 338 & 357 & 1.1 & 21 \\
\hline Opt. G92-4T & 600 & 4,562 & 600 & 345 & 368 & 1.5 & 23.5 \\
\hline Opt. G92-4T & 600 & 4,562 & 600 & 332 & 360 & 1 & 20.3 \\
\hline Opt. G92-4T & 600 & 6,445 & 600 & 318 & 351 & 1.4 & 19 \\
\hline Opt. G92-4T & 600 & 13,748 & 600 & 316 & 355 & 2.0 & 17.9 \\
\hline Opt. G92-4T & - & 0 & 650 & 272 & 303 & 1.6 & 20.2 \\
\hline
\end{tabular}




\begin{tabular}{|c|c|c|c|c|c|c|c|}
\hline Opt. G92-4T & 650 & 2,116 & 650 & 243 & 260 & 1.2 & 18.4 \\
\hline Opt. G92-4T & 650 & 5,284 & 650 & 256 & 280 & 1.5 & 31 \\
\hline Opt. G92-8T & - & 0 & 600 & 449 & 475 & 1 & 13.3 \\
\hline Opt. G92-8T & 600 & 1,152 & 600 & 447 & 479 & 1.2 & 17.1 \\
\hline Opt. G92-8T & 600 & 3,695 & 600 & 435 & 484 & 1.7 & 16.0 \\
\hline Opt. G92-8T & - & 1 & 650 & 385 & 428 & 1.3 & 16.3 \\
\hline Opt. G92-8T & 650 & 2,116 & 650 & 321 & 341 & 1.8 & 21.3 \\
\hline Opt. G92-8T & 650 & 5,284 & 650 & 298 & 318 & 1.1 & 21.7 \\
\hline G92-0 & - & 0 & 550 & 459 & 479 & 1.7 & 18 \\
\hline G92-0 & 550 & 5,000 & 550 & 451 & 476 & 1.4 & 20 \\
\hline G92-0 & 550 & 12,025 & 550 & 435 & 483 & 2.1 & 19.7 \\
\hline G92-0 & 550 & 19,926 & 550 & 448 & 490 & 1.5 & 20 \\
\hline G92-0 & - & 0 & 600 & 386 & 419 & 1.5 & 27 \\
\hline G92-0 & - & 0 & 600 & 395 & 413 & 1 & 26.3 \\
\hline G92-0 & 600 & 2,009 & 600 & 394 & 409 & 1 & 27.5 \\
\hline G92-0 & 600 & 4,589 & 600 & 335 & 392 & 2 & 17.8 \\
\hline G92-0 & 600 & 4,589 & 600 & 353 & 390 & 1.8 & 23.3 \\
\hline G92-0 & 600 & 7,557 & 600 & 382 & 394 & 1.3 & 20 \\
\hline G92-0 & 600 & 7,557 & 600 & 382 & 401 & 1 & 26.8 \\
\hline G92-0 & 600 & 14,979 & 600 & 370 & 404 & 1.7 & 23.2 \\
\hline G92-0 & - & 0 & 650 & 315 & 333 & 1.5 & 28 \\
\hline G92-0 & 650 & 1,348 & 650 & 279 & 295 & 1.3 & 26 \\
\hline G92-0 & 650 & 5,011 & 650 & 270 & 283 & 1.4 & 30 \\
\hline G92-0 & 650 & 10,546 & 650 & 257 & 268 & 1.5 & 32 \\
\hline G92-0 & 650 & 20,531 & 650 & 261 & 275 & 1.1 & 30 \\
\hline G92-0 & 650 & 36,061 & 650 & 250 & 270 & 1.2 & 30 \\
\hline
\end{tabular}




\subsection{Effect of thermal aging on microstructure}

Microstructural characterization was conducted on the Heat Opt. G92-4 of optimized G92 in the as-received condition and after thermal aging for $5,284 \mathrm{~h}$ at $650^{\circ} \mathrm{C}$. The microstructure of the as-received Opt. G92-4 has tempered martensitic structure with a high density of dislocations, $\mathrm{M}_{23} \mathrm{C}_{6}$ carbides decorated primarily along grain or subgrain boundaries, and a fine distribution of vanadium/niobium carbonitrides (MX) within subgrains. Thermal aging at $650^{\circ} \mathrm{C}$ caused significant microstructural changes, e.g. dislocation density and structural changes, subgrain coarsening, carbides and carbonitrides coarsening, and precipitation of a new phase, intermetallic Laves phase. Figures 10 (a) - (d) show representative TEM/SEM images of subgrains, dislocations within a subgrain, $\mathrm{M}_{23} \mathrm{C}_{6}, \mathrm{MX}$ and Laves phase precipitates in the specimen thermally aged for $5,284 \mathrm{~h}$ at $650^{\circ} \mathrm{C}$. Quantitative measurements of dislocation densities within subgrains, subgrain widths, and size distributions of $\mathrm{M}_{23} \mathrm{C}_{6}, \mathrm{MX}$ and Laves phase precipitates were conducted on the as-received and thermally-aged specimens, and the data are compared in Fig. 10(e). Note that the microstructural data of the sodium-exposed Opt. G92-4 specimen $\left(650^{\circ} \mathrm{C} / 4,370 \mathrm{~h}\right)$ was also included in Fig. 10(e).

Subgrains coarsened rapidly during thermal aging at $650^{\circ} \mathrm{C}$. The mean width of subgrains in the as-received Opt. G92-4 was $277 \mathrm{~nm}$, while the mean width of subgrains in the thermallyaged Opt. G92-4 was $492 \mathrm{~nm}$. The subgrain size distribution became broader, and subgrains with a much larger width formed during aging. The dislocation density within subgrains showed minimal changes after aging. Coarsening of $\mathrm{M}_{23} \mathrm{C}_{6}$ carbides and $\mathrm{MX}$ particles was observed in the thermally-aged Opt. G92-4 specimen. The mean size of $\mathrm{M}_{23} \mathrm{C}_{6}$ precipitates in the thermallyaged Opt. G92-4 specimen was $119 \mathrm{~nm}$, relative to $90 \mathrm{~nm}$ in the as-received specimen. The mean size of MX precipitates increased from $46 \mathrm{~nm}$ to $71 \mathrm{~nm}$ after aging for $5,284 \mathrm{~h}$ at $650^{\circ} \mathrm{C}$. Precipitation of Laves phase occurred during thermal exposures at $650^{\circ} \mathrm{C}$ in Opt. G92-4. The mean size of the Laves phase particles was $270 \mathrm{~nm}$. Laves phase precipitates were distributed primarily along grain/subgrain boundaries. Microstructural changes in Opt. G92-4 during sodium exposure were much more pronounced than under thermal exposure at $650^{\circ} \mathrm{C}$. 


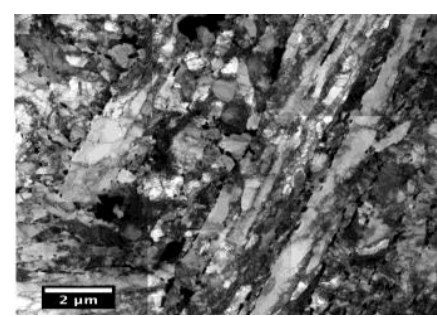

(a)
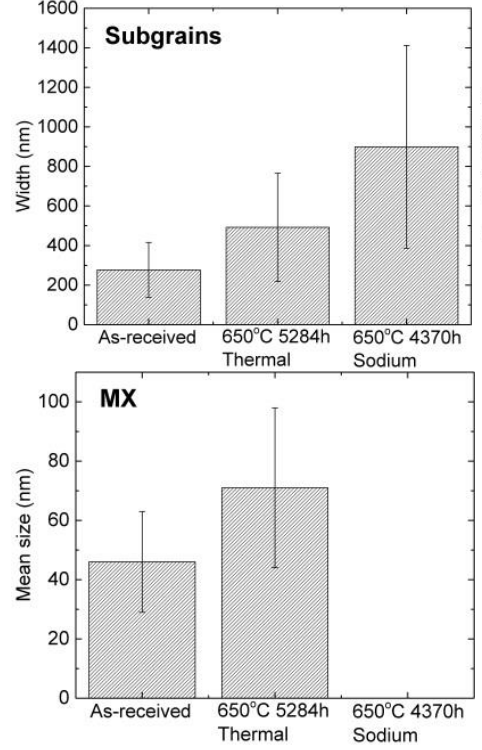

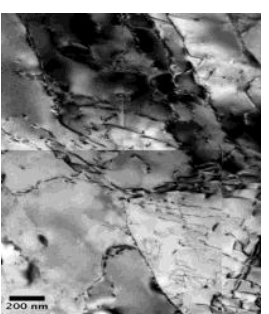

(b)
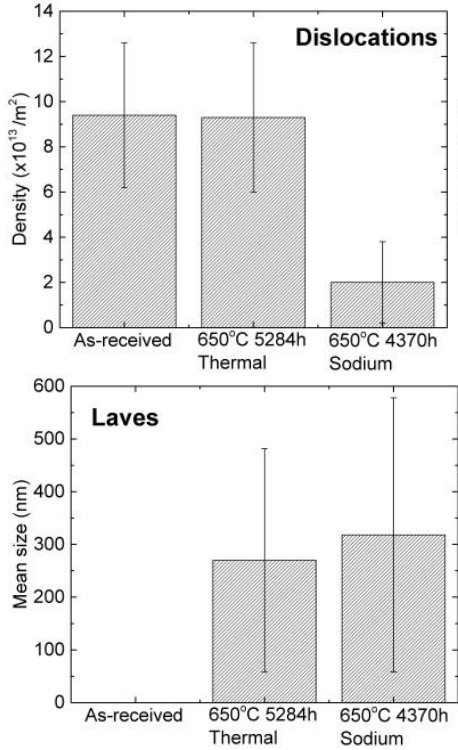

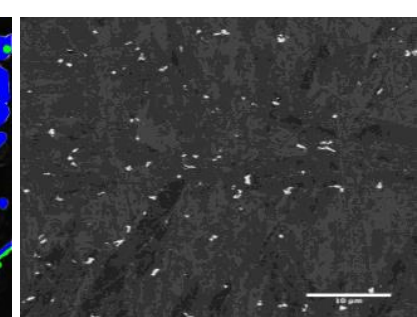

(d)

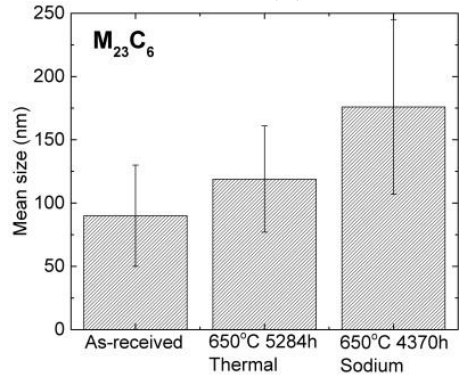

(e)

Figure 10. Microstructure of Opt. G92-4 after thermal aging for 5,284 h at $650^{\circ} \mathrm{C}$ (a) TEM image of subgrains, (b) TEM image of dislocations, (c) TEM image of $\mathrm{M}_{23} \mathrm{C}_{6}$ (colored in blue) and MX (colored in green) precipitates, (d) SEM image of Laves phase, and (e) comparison of subgrain width, dislocation density, mean sizes of $\mathrm{M}_{23} \mathrm{C}_{6}$, $\mathrm{MX}$ and Laves phase particles in the as-received, thermally-aged $\left(650^{\circ} \mathrm{C} / 5,284 \mathrm{~h}\right)$, and sodium-exposed $\left(650^{\circ} \mathrm{C} / 4,370 \mathrm{~h}\right)$ conditions. 


\section{Summary}

This report provides an update on the evaluation of the effect of thermal aging on tensile properties of existing laboratory-sized heats of Alloy 709 austenitic stainless steel and the completion of effort on the thermal aging effect on the tensile properties of optimized G92 ferritic-martensitic steel.

Thermal aging experiments at 550,600 , and $650^{\circ} \mathrm{C}$ were carried out on three laboratorysized heats of Alloy 709 austenitic stainless steel, 709-01 (SAI Heat 12013806-709), 709-02 (CarTech Heat 11367), 709-05 (CarTech Heat 011502). Tensile tests were conducted at the aging temperature in air at a nominal strain rate of $0.001 \mathrm{~s}^{-1}$. It was found that thermal aging at $550^{\circ} \mathrm{C}$ had minimal effect on the tensile properties for times $<10,000 \mathrm{~h}$. Thermal aging at $600^{\circ} \mathrm{C}$ for $\sim 15,000 \mathrm{~h}$ slightly increased the yield stress and decreased the ultimate tensile strength (UTS). The effect of thermal aging at $650^{\circ} \mathrm{C}$ was more pronounced on the tensile properties of Alloy 709. An increase in the yield stress and a decrease in the UTS were accompanied by the reduction in the uniform and total elongations. The yield stress was increased by $\sim 34 \%$, the UTS was reduced by $\sim 9 \%$, and the uniform and total elongations were reduced by $\sim 50 \%$ and $\sim 36 \%$, respectively after aging for $\sim 20,000 \mathrm{~h}$ at $650^{\circ} \mathrm{C}$. The effect of thermal aging on tensile properties showed little variations among three heats of Alloy 709.

Four heats of optimized G92 ferritic-martensitic steel with or without thermo-mechanical treatment (TMT), including Opt. G92-3, Opt. G92-4, Opt. G92-4T, and Opt. G92-8T were investigated to evaluate the effect of thermal aging on the tensile properties of optimized G92. Conventional G92 (Heat G92-0) was included in the study to provide the baseline data. Thermal aging at $550-650^{\circ} \mathrm{C}$ caused a decrease in the yield stress and the ultimate tensile strength but had an insignificant effect on tensile ductility of optimized G92. The effect of thermal aging was stronger at higher temperatures and longer exposure times. The effect of thermal aging on tensile strength became evident after $\sim 10,000 \mathrm{~h}$ at $550^{\circ} \mathrm{C}, \sim 1,000 \mathrm{~h}$ at $600^{\circ} \mathrm{C}$, and $<1,000 \mathrm{~h}$ at $650^{\circ} \mathrm{C}$. The aging-induced reduction in tensile strength was much more pronounced at $650^{\circ} \mathrm{C}$ than at temperatures of $550-600^{\circ} \mathrm{C}$, and exhibited large variations among different heats of optimized G92. The heat with a higher initial tensile strength (e.g. Opt. G92-3 and Opt. G92-8T) showed a much greater reduction in strength than those with lower initial tensile strength (e.g. Opt. G92-4 and Opt. G92-4T). Microstructural characterization of optimized G92 showed subgrain coarsening, coarsening of $\mathrm{M}_{23} \mathrm{C}_{6}$ and $\mathrm{MX}$ particles, and precipitation of Laves phase after thermal aging at $650^{\circ} \mathrm{C}$. These microstructural changes can be correlated well with aginginduced tensile property degradation at $650^{\circ} \mathrm{C}$. 


\section{Acknowledgement}

This research was sponsored by the U.S. Department of Energy, Office of Nuclear Energy, for the Advanced Reactor Technologies (ART) Program under Contract DE-AC0206CH11357. We gratefully acknowledge the support provided by Brian Robinson of DOE-NE, Advanced Reactor Technologies, ART Program Manager; William Corwin of DOE-NE, Advanced Reactor Technologies, Materials Technology Lead; Robert Hill of Argonne National Laboratory, ART Co-National Technical Director; and Sam Sham of Argonne National Laboratory, ART Advanced Materials, Technology Area Lead.

Materials were provided by the Oak Ridge National Laboratory. D. L. Rink is thanked for specimen encapsulation. M. Quesinberry is thanked for maintaining furnaces and conducting tensile tests.

\section{References}

[1] Busby, J. T., S. Byun, R. Klueh, P. Maziasz, and J. Vitek, K. Natesan, M. Li, R. Wright, S. Maloy, M. Toloczko, A. Motta, B. D. Wirth, G. R. Odette, and T. Allen, "Candidate Developmental Alloys for Improved Structural Materials for Advanced Fast Reactors," ORNL/GNEP/LTR-2008-023, March 2008.

[2] L. TAN, et al., "Creep resistance and fracture toughness of recently-developed optimized G92 and its weldments for advanced fast reactors," IAEA-CN-245-50, 2017. 



\section{Argonne}

Nuclear Engineering Division

Argonne National Laboratory

9700 South Case Avenue

Argonne, IL 60439

www.anl.gov 